Please do not remove this page

RMIT

UNIVERSITY

\title{
Aristotle Meets Youth Work: A Case for Virtue Ethics
}

Bessant, Judith

https://researchrepository.rmit.edu.au/esploro/outputs/9921863878401341/filesAndLinks?institution=61RMIT_INST\&index=null

Bessant, J. (2009). Aristotle Meets Youth Work: A Case for Virtue Ethics. Journal of Youth Studies, 12(4), 423-438. https://doi.org/10.1080/13676260902866843

Document Version: Accepted Manuscript

Published Version: https://doi.org/10.1080/13676260902866843

Repository homepage: https://researchrepository.rmit.edu.au

Downloaded On 2023/04/26 21:55:27 +1000

Please do not remove this page 
Citation:

Bessant, J 2009, 'Aristotle Meets Youth Work: A Case for Virtue Ethics', Journal of Youth Studies, vol. 12, no. 4, pp. 423-438.

Journal of Youth Studies, Vol. 12 No 4, pp. 425- 440. in press.

\title{
Aristotle Meets Youth Work: A Case for Virtue Ethics
}

\author{
Judith Bessant, RMIT University
}

\begin{abstract}
What ethical framework provides the best guide for contemporary youth work is the central question in this article. An account is provided of why the two dominant ethical frameworks, namely, utilitarianism and deontic ethics are not appropriate. It is argued that virtue ethics is most relevant because it specifies the nature of social goods, and provides a relevant framework of thinking about good practice. Six key reasons are identified for why virtue ethics provides the most suitable ethical framework. They include its account of virtues expressed in our character, its focus on education to build character as a source of social transformation, its emphasis on our agential capacity to make choices, its interest in our capacity to think critically and act ethically, the connections it makes between the practice of virtues and social goods that define a good life individually or collectively, and its capacity to inform good professional judgment and good practice. What all this means for youth work is considered through a discussion about good judgment and practice - or to use the virtue ethics vocabulary, 'phronesis'. What that means in terms of the requisite skills, knowledge and dispositions is spelt out in relation to youth work practice.
\end{abstract}

Ethical questions like 'how should I live' and 'what is the right or fair thing to do' challenge us every day. They are questions that are also part of a two and half thousand year history of philosophical discussion in the west. And, whether we always realize it or not, our ways of answering these questions and our personal and professional practices draw on those traditions which are as diverse as Aristotelianism, natural law theory, rule-based ethics, and utilitarianism.

Today we witness a contemporary rediscovery of ethics in western societies. As John Finnis (1980) and Bent Flyvbjerg (2001) observed this revival is surprising given the influential arguments mounted against the idea of practical reasoning through the twentieth century. The dominance of scientific materialism for example seemed to threaten the idea of ethical discourse while Max Weber (1967) argued it was essential that the social sciences engage with the world in value-free ways. Meanwhile A.J. Ayer (1947) using the alleged fact /value distinction argued that to talk about ethical values was to talk emotional nonsense. Yet not even a modest degree of reflection description or analysis of our social world is possible without considering what is good for people (Putman 2004). In other words, it is simply not possible to avoid ethical evaluations because, to paraphrase Aristotle, all human action is informed by ideas about what is good and bad and how we ought to act.

Whether it was the recognition that human action is always informed by ethical ideas which stimulated the contemporary enthusiasm for 'values', it is clear that business, government agencies and non-government organizations now routinely produce Codes of Ethical Practice, and promote themselves as ethical 'corporate citizens'. Likewise, public institutions like hospitals and universities have established elaborate committee systems with manuals of rules and 'ethical guidelines' or regulations designed to manage the ethical dimensions of research and practice in moral ways. A range of professions like medicine, accountancy, the law, psychology and social work also regularly debate, release, implement professional codes of ethics. Against this general background we can situate the move by many youth peak bodies and professional youth work organisations to produce codes of practice or codes of ethics (YACvic 1996; Sercombe 1998; YACWA 2003; NYA 2004; Banks 1999 and 2004; Grogan 2004).

In this article I ask what kind of ethical ideas provide the best guide for contemporary youth work? This question matters because professional practice as a form of human action is always informed by ethical ideas, many of them drawn -sometimes unwittingly- from one or more of the major ethical traditions. Moreover, most codes of ethics tend to adopt declaratory or exhortatory stances which 
identify the bad conduct to be avoided or prohibited, while steering away from the task of specifying the values or goods to which a practitioners may commit themselves, or which can provide a criteria for identifying good practice. While those engaged in producing various codes seem to appreciate the need to at least consider the value of identifying codes of ethical practice, less energy has been expended on addressing the question of what kind of ethical frameworks might have value or how coherent those ethical ideas ought to be.

I work from the assumption that it is preferable to have clarity about the 'social goods' that youth work promotes as well as being able to acknowledge that not all ethical frameworks or traditions are equally able to articulate what those goods are. I argue that 'virtue ethics' can be used to identify good youth work practice and indeed that a natural affinity exists between youth work and virtue ethics. Virtue ethics is one of the oldest western philosophies with its origins in Classical Athens and the work of philosophers like Socrates, Plato and Aristotle. The influence of virtue ethics diminished as Christianity achieved institutional and political hegemony in Europe. For most of the last millennia, ethical philosophy in the West was dominated by various Christian theologies and natural law and then from the eighteenth century on by utilitarianism in the Anglo-American world and by a Kantian deontic ethics in Europe. While generalizations about the hegemonic status of the various ethical traditions can be contested it can be said with some confidence that utilitarianism has provided the most widespread ethical framework in countries like Britain, the USA and Australia across the last few centuries.

Before I consider the value of virtue ethics it is useful to briefly review utilitarian and deontological ethical theories. I argue that the utilitarianism and deontic traditions in their various forms reveal major intrinsic limitations in terms of their capacity to supply a credible framework of good practice for professions like youth work. I then turn to virtue ethics and suggest why it offers a more useful vocabulary and framework for modern youth work.

\section{Utilitarianism}

Utilitarianism has provided a long-standing framework of ethical deliberation since its origins in Britain courtesy of eighteenth century philosophers like Francis Hutcheson and Jeremy Bentham. Utilitarianism has played a key role in shaping the framework of Anglo-American public life and many core modern institutions and practices including the parliamentary and justice systems, political liberalism and the 'welfare state'. Utilitarianism is also mansion with many rooms requiring a rather thick book to provide an adequate account of it. The brief synopsis offered here can only gesture at that complexity and richness. Like all major philosophical traditions utilitarianism is defined as much by the internal disagreements amongst its adherents as by the things they agree on. The fact that contemporary philosophers as diverse as Shelly Kagan, J.J.C. Smart, Peter Singer and Peter Railton have articulated versions of utiltarianism highlights the point that a clear and firm common ground that can be used to define this tradition is often hard to find.

In its original formulation developed by Hutcheson and Bentham, the principle of utility was grounded in a hedonistic doctrine that defined pleasure and/or the avoidance of pain as the criterion for establishing what was good or bad. According to Bentham we are motivated by the desire for pleasure and desire to avoid pain. This form of utilitarianism is an 'ethical hedonism' expressed in the injunction: to always act so as to promote the greatest happiness, and can be characterized as a kind of psychological hedonism involving a preoccupation with motivation.

Subsequent utilitarians rejected the idea that the good is whatever satisfies human desire or what makes us happy. We saw for example the emergence of 'Rule Utilitarianism' whose proponents urge that we follow rules like 'never lie or kill', as well as 'Act Utilitarianism' whose advocates encourage us to generally follow rules but allow for exceptions so as to allow for one's own judgment. (The nineteenth century utilitarian J. S.Mill wavered between these two strands). Then there are those who advocate for 'Direct Utilitarianism' and who rely on a form of instrumental evaluation that says we can know acts are right by the overall wellbeing those acts produce.

One way of indicating the complexity and tensions inherent utilitarianism is to refer to a few similarities and differences in the work of two key figures - Bentham and J.S. Mill. (The fact that key figures in this tradition like J.S Mill changed their minds repeatedly about some aspects of 
utilitarianism both across their lifetime and as they engaged in a range of disciplinary problems presented by moral philosophy, political theory, or economics, highlights the complexity of this tradition).

While Bentham and Mill agreed that the right thing to do is to maximise happiness, Bentham had a particularly instrumental view of that, arguing that we can aggregate the interest of each person through a formula which calculates the goodness of an act. His felicific calculus entailed adding up the total amount of pleasure, subtracting the pain and multiplying the number of people affected. Mill however thought it was more complicated and had a more thoughtful approach that entailed acknowledging the quality of satisfaction of desire. He also observed there were higher and lower forms of pleasure and pain. According to Mill an act could be justified partly by its utility, as well as by its contribution to liberal society. Mill was not entirely comfortable with Bentham's approach partly because he (Mill) tacitly accepted the quite different Aristotelian concept of 'happiness' or eudaimonia - a life that entails a plurality of valuable activities relating to our ethical, intellectual and political excellences. As Nussbaum argued, Mill never fully grasped the tensions between these two notions of happiness and for this reason never explicitly described the conflicts or argued for the way he had appropriated elements of both Bentham and Aristotle (2004, pp.60-68).

While internal critique characterise this tradition, utilitarians have also faced on-going and often damaging critical assessment from 'outsiders' like Kant, Sedgwick, and Green, and more recently from Finnis, Posner, Williams and Sen to name but a few.

These critics variously argued firstly that relying on happiness, pleasure or wellbeing as utilitarians do, cannot provide a strong, stable or consistent enough basis upon to determine whether an action is good or right. There are simply too many ways happiness (or wellbeing or pleasure) can be described and achieved. Partly this is because what produces happiness, well-being or pleasure changes with time and place, such that what evokes happiness or wellbeing in one time or place may not in another.

Secondly, there is the related problem of whether different degrees of happiness should be given different ethical significance? Are some forms of happiness more important than others, or is the happiness of one equivalently sized group more important than that of another same sized group? And, should the absence of certain pains have greater weight than the absence of others? (This was a key point of contention between J.S Mill and Bentham).

Thirdly, utilitarianism leaves young people (as a numerical and moral minority) reliant on the hope that securing the interest of young people will satisfy the desires and diminish the pain of the majority (older people). This means older people (as the majority) always have priority over 'the young' and that the well being or interests of young people is whatever satisfies the desire of older people as the majority. As I soon argue, this is not a good basis for determining the morality or goodness of an act or for determining what is in the interest of young people. It also diminishes the voice of young people and their right to participate in decisions in which they have a direct interest.

Moreover, to claim that morality can be determined by the degree to which an act satisfies desire or relieves pain or creates wellbeing while ignoring the quality of the action used to create that happiness is not a defensible way of identifying the good. This is because action cannot be good if it is wrong in the first place. Indeed there are activities that give some people great pleasure which are evil and supporting or engaging in such action can never be moral. For example, it cannot be moral to subjugate a minority (ie., young people, women etc) because the consequences of that action maximise happiness and relieve pain for the greatest number (older people, men). It is an approach that is problematic for young people in 'the West' and particularly in the context of an ageing population. And even in instances where the young are a demographic or numerical majority (ie., in most 'developing countries'), they remain a political minority in terms of their capacity to have their voices listened to or to have influence. In short, because 'youth' as a cohort are less powerful than most other age groups, they are as a permanent minority subject to the tyranny of the majority and recurrently marginalised.

The idea that it is moral to discriminate against a minority if it satisfies the interest of the majority cannot be described as just or good action, and for this reason utilitarianisms is not a suitable ethical framework for guiding youth work practice. There are cases where the neglect and abuse of young 
people satisfied certain notions of wellbeing for the majority. We need only consider policies like the forced and mandatory removal of generations of indigenous children from their families and communities in countries like Australia and Canada (HREOC, 1997). Likewise the systemic abuse and neglect of young people at the hands of 'carers' in many church and the state sponsored organisations through the twentieth century certain produced a utility for a majority, but can never be considered just or moral action (Gill, 1997). While these actions may have been justified by reference to the interest of a majority, they were not ethical practices. This problem relates more broadly to the issue of evil pleasure. If a person or a community get pleasure from harming others does that make it those people better? With these questions in mind I argue that utilitarianism cannot provide an adequate ethical framework for youth work.

Fourthly, if a youth worker applies utilitarian principles this can constrain their capacity to exercise a duty of care and professional discretion because these require that the individual identify what contributes to their own wellbeing. If for example a young person considers chroming (inhaling aerosol vapors) to the point of unconsciousness contributes to their wellbeing, then is it ethical for the youth worker to support that practice? I argue it is not because while the worker has an obligation to respect the young person's autonomy, they also have an overriding duty of care or fiduciary duty.

Similarly, if we accept the justification of a policy designed to exclude young people from a public space because it satisfies the interest of the majority, then is the worker's capacity to exercise professional judgment and advocate for and with young people constrained? Indeed except in the case of Act utilitarianism where some room is left for judgment, utilitarianism -and particularly rule utilitarianism- tends to makes professional judgment redundant because what is good or right has already been determined and is universal regardless of the particular circumstances. The same problem applies in respect to the exercise of fiduciary duty. Given these constraints on a youth worker's capacity to exercise professional judgment and fiduciary duties, utilitarianism is not an ethical framework that suitable for youth work.

This also raises the question about whether the youth worker can act morally when the source of their judgment is not their conscience or their own sense of what is right and wrong (Williams 2006).

Fifthly, the relationship between the youth worker and young person which is fiduciary in nature (ie., carer, beneficiary) imposes duties on practitioners to act in ways that protect the interests of the young person. Utilitarianism constrains a worker's capacity to exercise those duties because being a fiduciary means acting in the young person's interest even when that involves acting against the interests of the majority - or against what the individual say contributes to their well being.

Finally, there is the question of distributive justice, which refers to the just allocation of goods and services, frequently understood in liberal terms as the idea that a 'just society enables its citizens to pursue their own ends consistent with a similar liberty for all' (Sandel 1984: 81). According to critics of utilitarianism like Rawls, when utilitarians working from the welfare maximizing tradition attempt to secure the general welfare they overlook the distinctions between people and treat society as a single entity because they are preoccupied with a single idea of well-being that ought to be maximized. This reflects a failure to recognize the plurality of a community and the distinctiveness of individuals and/or groups within that society and means that the different needs/desires found in any society are not acknowledged. The failure to attend to difference means that different persons and groups are neither acknowledged nor respected as ends in themselves. This affects groups like young people especially as it encourages avoiding the effect of power disparities between older and younger groups. Approaching youth work as an exercise in promoting the well being of the whole community for example would entail overlooking the fact that young people typically have far less access to resources, and relatively little say when it comes to determining public policy and provisions for youth related services in state and national budgets. Distributing benefits in order to promote an idea of the general welfare is unjust because there are no guarantees that young people either collectively or individually would get the kind of distribution they need to fully develop.

If the utilitarian framework in its various forms is inadequate a guide for ethical youth work practice, how well does deontological ethics do?

\section{Deontology}


Advocates for the deontological tradition argue that a defensible ethical position can be known by the degree to which you follow particular principles, rules or duties (rather than the rightness or wrongness of the consequences of actions).

Like utilitarianism, the deontological tradition consists of clusters of related theories. Having said that however it can be argued that part of the common ground for proponents of deontology their to specify the kind of rules which are right and why they are right. Immanuel Kant's 'Categorical Imperative' is one such rule developed to address the question of justice by requiring us to always treat others as ends in themselves and also by ensuring we always act as if our own actions will be adopted universally. In other words, always do to others as you would like others act towards you. Kant argued that if we obey this rule then we achieve justice. Kant as a deontologist argued we must always act according to duty (ie., if we do not want others to kill us then we must never kill others). Others like Ross (1930) argued for a less austere set of rules found in his 'representative or pluralistic deontology' in which he articulated seven prima face duties or aspects of moral action which included our duty to help others, to avoid harming others, to improve ourselves, to ensure other get what they deserve, and that we act according to promises made. More recently deontologists like Kamm (2007) qualified this further by articulating 'the Principle of Permissible harm' that says when it is morally right to make exceptions and harm others and thereby allow for some individual judgments.

While this heterogeneous tradition has many strengths it also has a number of flaws that limit its suitability as a guide for youth work practice. One limitation is evident in the work of Kant and his highly individualist notions of the self which privileges individualistic values. (It is also worth noting that this perspective is shared by liberal social and political theorists). In his quest to emphasise the rational basis of his construction of his ethics Kant stripped human existence of all the rich, complex social and psychological qualities producing an ethical theory without content. This approach cannot be taken seriously because young people (like people of all ages) are social and typically deeply connected to the communities in which they live which change with time and place and according to the particular cultures that characterize the communities.

Secondly, the kind of deontic approach exemplified by Kant, and also in Rawls (1971) account of justice, fails to say exactly what social goods or justice are, or what it is that we owe to each other. Given this absence, applying such a framework to youth work would not help practitioners articulate what the social goods are that they aim to achieve when they exercise certain duties. Similarly, it does not help youth workers recognize what their obligations are towards young people, or what young peoples obligations are towards others (beyond acting to ways one would like to be treated themselves or by obeying Ross's seven duties).

Thirdly, deontic philosophers neglect the role of power and so cannot say how differences in authority, influence, wealth and status relate to the task of achieving what is good or just. Yet any workable theory of justice, especially as it relates to less powerful groups, like young people, needs to address the fact that such differences can create unfairness and impede attempts to address inequities and unfairness.

Finally, while ethical rules like the Kant's 'categorical Imperative' can help by reminding youth workers to consider whether they would be prepared to be on the receiving end of their own actions, the requirement to always obey a rule like the Kant's Categorical Imperative is not so easy and indeed not always possible. Even if we soften or qualify this by using Kamm's modification, it remains a tall order and unclear how and when it is right and good to make case judgment.

Kant's requirement that we must always 'do unto others...' to achieve the good or justice is difficult to achieve and one that many people may fail. This practical issue raises doubt about the reliability and viability of that principle as a guide for action or practice. Given these observations, I argue that the deontological tradition fails to provide a credible guide for youth work.

Why then does virtue ethics offer a better ethical guide for youth work practice? The short answer is that it provides clear and helpful descriptions of social goods and the ways we may live a good life.

\section{Virtue Ethics}


Unlike both the utilitarian and deontic traditions which attempt to elucidate the principles or rules which enable a person to work out what to do in a given setting, proponents of virtues emphasize the role of character. For those working in this tradition being a good person is more important than knowing about the rules or principles of ethical judgment: doing the right thing is understood in terms of the virtues a person displays. The idea of 'virtue' itself refers to good habits and dispositions to display character traits like courage, prudence, rationality or temperance.

This tradition has its origins in classical Greek period and the work of philosophers like Socrates, Plato and Aristotle who spoke about the good, why the practice of virtue was important, and how to promote 'human flourishing'. From the mid-1950s on virtue ethics has enjoyed a revival instigated by a group of modern writers including Elizabeth Anscombe (1958) who wrote an essay Modern Moral Philosophy, Philippa Foot who produced books like Virtues and Vices (1978), Alasdair Maclntyre who published After Virtue in the 1971, Bernard Williams (2006) and Martha Nussbaum (2000). In Australia Justin Oakley (1993; see also Oakley and Cocking ,2001) and Stan van Hooft (2006) have contributed towards the revival of virtue ethics.

Given both its longevity and the number of writers associated with this tradition we again face the difficulty of acknowledging diversity while being able to identify some of the common threads. For Socrates and Aristotle, virtue was the basis of collective justice and of a life lived well which for Aristotle was the pursuit of eudaimonia or flourishing. For the Greeks it was self-evident that being human meant giving the fullest expression to our in-built capacity to be rational, and that to act according to our nature is to act according to the light of reason which is a quintessential component of being human flourishing or happiness (see Foot, Hursthouse).

Modern virtue ethics saw the emergence of what has been called an 'agent based' approach which focuses on a person's (agent's) motives rather than the more traditional focus on virtues (Slote 2001). Also in the last few decades feminist philosophers developed an 'ethics of care' which critiques 'masculine' ideas of justice or agential autonomy, arguing that this privileged 'male experience' at the expense of women's commitment to virtues like care for others and self-sacrifice (see Claire Baier). Equally comparing the work of two key virtue ethicists like Martha Nussbaum and Bernard Williams further highlights to the heterogeneity of virtue ethics. While both shared an interest in feminist ideas, Williams was skeptical of the importance given to rationality, reason and theory in ways Nussbaum sought to defend. This reminds us that like the other traditions, those philosophers who have focused on the idea of virtue do not belong to a single coherent movement, but are better seen as working inside complex webs of ideas who draw on a shared vocabulary and share a consensus about the common problems they face.

A key element of virtue ethics involves understanding how we identify ourselves as a particular kind of person. That is why most virtue ethicists emphasize that our capacity to act well is based on our 'character'. In its modern form, the focus continues to be on the person and idea that certain dispositions to act in virtuously (ie., to be compassionate, courageous etc.,) remains relatively stable. For Williams (2006) there is a distinction between morality (concerned mainly with ideas of duty and obligation) and ethics (a wider concept of a good life that includes emotions). He also argued that we need to acknowledge the role of luck and what is beyond our control in judging the a person's virtue. This is because our capacity to act ethically depends on our upbringing, our education and the opportunities we have to develop our 'character'. He argued that some people through bad luck or for no fault of their own do not have access to decent education, good role models or supportive social networks. With this caveat in mind, Williams like other virtue ethicists, argue that 'character' refers to a temperament towards optimism or pessimism, as well as one's feelings, thoughts and capacity to exercise good judgment.

Most virtue ethicists claim that we each have particular sensitivities, gifts, interests or abilities which are part of who we are and become part of our character. Character reflects the sum of a person's life experience, training, luck and the quality of their relationships, and informs what and how we feel, think and act in given situations, and orients us toward certain wants, desires and emotions (Williams 2006). This emphasis on cultivating or nurturing the range of virtues and things we are good at has both a personal and a social dimension. To live a good life those abilities need to be recognized, nourished and developed for and by each person. We might think for example of the young person 
with a sensitivity or aptitude for music, or an athletic gift expressed in playing football or running. Thus to live well, and to flourish that young person needs opportunities to make music, play football or run as well as they possibly can. Yet as virtue ethicists since Socrates have insisted there is also a collective dimension. That is we each have a common interest in a shared life in which everyone can thrive. Caring for others for example helps strengthen and enrich our social relations and the lives of others by conferring goods on them.

If we are to thrive or flourish personally by cultivating virtues like courage, honesty, self control, critical thinking, generosity, forethought, a commitment to justice or fairness, loyalty and care we also may see that everyone will benefit if all are enabled to flourish. That is virtue ethicists have not sanctioned a self-regarding or egotistic practice of virtues for the benefits they confer on the individual alone. The point of pursuing our own 'excellence' is to promote our dispositions in ways that also assist others to pursue theirs. That is we can only lead a flourishing life in a context where others also do so. 'A life well lived' can be possible by identifying and practicing being good at those things for which we have particular dispositions.

If the point of this discussion is to demonstrate the usefulness of virtue ethics and how it might inform good youth work practice, some clarity about the nature of youth work.

\section{Youth Work and Why virtue ethics?}

Thinking from the perspective of virtue ethics helps to approach the purpose and practice of youth work freshly. In considering what youth work is it needs to be acknowledged that like other forms of social intervention (such as social work or community development) that it is not a straight forward question to which there can be a simple descriptive answer. For example, while youth work in the UK has a strong professional association and relative consensus about its nature and the elements that can be used to describe practice (Davies 2005, Jeffs and Smith 2008, pp. 277-302), that does not mean we can conclude that is the case universally. (Indeed even while there is relative consensus in the UK the literature also points to a high level of debate about the nature of youth work (Young 1999, Jeffs, \& Smith, 2002, pp. 39-65; Davis 2005, Spence et.al 2006). And apart from important differences between countries (Males 1999, Palmer 2003, pp.11-18; Skott-Myhre 2008, Hamilton and Hamillton 2007) there are also different sites of intervention (eg., schools, drug and alcohol services, youth housing, child protection, community arts, youth justice), that sustain different kinds of practice. In short as Smith (1988) argued, we cannot point to a narrowly conceived form of youth work possessing commonly agreed characteristics and a single skill set or singular identity.

Yet having acknowledged that, we can still say that youth workers, operating across often radically different institutional sites, times and communities have shared a general intent to seek the development of young people as human beings. This can be described as a commitment to working with young people to shape their character and to do so in ways that refer to virtues like displaying courage, being honest, thinking critically, pursuing knowledge and having good sense. This general intent can be observed when we consider the various practices of youth work historically and cross culturally. While I cannot offer a comprehensive survey here we might refer for example to the nineteenth and early twentieth century emphasis on shaping a kind of 'muscular Christianity' among young men (eg., the YMCA, the Boy Scouts, the Try Society etc), or on a mixture of useful and decorative femininities for young women (eg., domestic science, YWCA, Girl Guides) (Young 1999). While we might now see in these exercises the manifestation of doubtful notions of masculinity, femininity or racism, we should not doubt that these exercises were informed by a context specific view of flourishing. Today we might use the language of 'identity formation' or 'development' rather than 'character', as youth workers promote ideas like participation, citizenship, community engagement or what Skott Myher (2008) describes as 'radical youth work' (based on recognising various forms of oppression), or specific kinds of youth work like indigenous youth work (Palmer 2003, pp.11-18). The point remains: the intention is to cultivate character by guiding young people towards certain ideas about how to lead a valuable life.

In saying this I do not want to be understood as implying that ideas about being a certain kind of person possessing certain virtues have either a timeless or an essential quality. Clearly people have very different ideas about what constitutes a virtue. Our ideas about virtues cannot help but be grounded in a particular time and place. All ideas about desirable virtues-as-character-traits are generated by the community in which those virtues are to be practiced. They may even have 
attributed to them a self-evident quality and may even be treated as universal in scope and value. Our ideas about these virtues are also typically judged by reference to 'regulative ideals' whether they are grounded in religious beliefs, ethical discourses about 'goods' or 'human rights'. In other words, they are subjected to moral evaluation, thinking and practice that allows people to renew and change their culture and virtues (Maclntyre 1971). As Koonz (2004) eg., argues when considering virtues like courage or ethical ideas about the value of community solidarity, context is everything: the Nazi ethic while it valorised both courage and community did so in pursuit of exterminatory policies which have rightly been universally condemned.

With this caveat in mind if it is agreed that youth work is about the development of character and the practice of certain virtues then it seems clear that youth work has a natural affinity with the tradition of virtue ethics. To explore the affinity further I now consider how virtue ethics provides a number of resources and vocabulary and why they are valuable.

To begin, virtue ethics offers a degree of prescription where it is needed, namely in identifying basic goods to which youth workers can guide their practice. It also promotes the idea of good judgment (or phronesis) as a flexible yet principled foundation that can be applied to a variety of practices across different sites of intervention. Finally the tradition of virtue ethics warrants a degree of optimism about the value of education and training as the basis for developing good judgment and a flourishing life both for youth workers and the young people with whom they work.

\section{The Goods}

Ours' is a time when a willingness or the capacity to engage in a specification of the ethical point or purpose of social interventions is often either poorly done or not at all. Consequentialist oriented managerialist policy talk about 'better outcomes' for example which are typically accompanied by inadequate resourcing for the tasks at hand for example inspires little enthusiasm. So too do policies and practices that allow for the prevalence of high levels of youth and child poverty and inadequate child protection systems in contexts of modern affluent societies. Virtue ethics offers a valuable practical framework for youth work because it specifies a number of basic social goods, and in so doing provides clarity about values or what is good or bad. In this way it provides a strong foundation for youth work practice that can be used to achieve goods like a healthy life which is important if a young person is to flourish.

Yet reaching agreement about what these 'goods' are is not easy and likely to be a controversial exercise because ideas about what the goods that are desirable may not be shared widely, or even at all by others in a given communities. This raises the question of whether we can identify goods that are acceptable to all?

To explore the idea that there are fundamental human goods I refer to Finnis (1980) and Naussbaum (2000) to argue that it is possible to define 'intrinsic' goods. A good life is one in which young people and practitioners can develop in all the ways they are intrinsically able to; something that rests on the availability of the material and moral support needed to live such a full life which includes the following:

1. A healthy biological life is social good that relies on access basic material goods like housing, nutrition, adequate health care and a supportive social context.

2. Meaningful social being includes sociability and significant social relations as well as the ability to form and maintain a range of attachments and identities. It is a social good that extends to human and non-human life as well as objects. This also supports the right to love, grief, experiences of desire and appreciation. It is a social good that also relates to individual and collective identity like being able to know about and express ones own cultural or ethnic identity.

3. Aesthetic Goods. An imaginative full life is a good that rests on the availability of opportunities and the means available to appreciate and give expression to beauty, creativity and innovation. This is broader than simply finding pleasure in the dominant icons of one's culture, or the chance to visit galleries or make art. Rather it extends to a young person's capacity to value and enjoy beauty in movement, numbers, sound and the natural world. 
available to all regardless of religion or creed. It refers to the opportunity to purse eternal verities or 'the profane'.

5. To form a conception of what is good, or to be a virtuous person includes engagement in critical reflection and capacity to plan one's own life.

6. To play and enjoy recreation. This goods rest on being able to access to the material resources, knowledge, skills and emotional security to enjoy pleasure through play, simple amusement.

7. To work or labour (in ways that are not oppressive) is a social good that allows for enjoyment of one's industry, and provides opportunity to help shape the world economically socially and culturally.

For virtue ethicists these goods are universal in the sense they are valued for their own sake and not as a means to another end regardless of social context. This does not imply uniformity in respect to their form or how they are applied because being sensitive to ones context is critical. This means the content or form deemed appropriate for achieving a social good in one context is likely to be different for other places or cultures.

As mentioned above, according to virtue ethicists the community in which a virtue is to be practiced or a social good located, is where decisions about their form and content ought to be made. Moreover, I suggest that deliberative democratic processes that are inclusive of young people provide the best way of reaching such agreements. Indeed the idea of un-coerced discursive approaches to consensual decision making have been central to many attempts in the western tradition to describe the means by which politics is best conducted. From Plato through to Aristotle to contemporary theorists like Strauss, Rawls and Lakoff the western political tradition has acknowledged the importance of discourse and language generally in constituting and defining the ethical and political.

How practitioners support young people so they can develop and enjoy a variety of social goods differs according to the context. The task of the youth worker is firstly to be clear about the nature of the social goods needed to enable young people (and citizens generally) to 'thrive'. Secondly it entails being willing and able to engage in practices of deliberative democracy like discussion, criticism and reflection in ways that secure agreements about the form and content of those goods and how - in quite practical ways- they can be secured. Thirdly, it requires phronesis (or good judgment) and conduct in which virtues like courage, fortitude, endurance, generosity, and humility are displayed. These entailments help define good youth work.

\section{Good judgment/good practice}

Good youth work requires a capacity to exercise both professional judgment and then to act in ways that are aligned with that judgment. This capacity will play its part in shaping the extent to which their 'client' can lead a flourishing life.

'Phronesis' draws on what virtue ethicists call an 'intellectual virtue' which guides practitioners in knowing how to feel and act in a given situation. This is something that relies on experience. As Damasio observes, good judgment depends on 'how well we have reasoned in the past; on how well we have classified the events of our past experiences in relation to the emotions that preceded and followed them; and also on how well we have reflected on the successes and failure of our past intuitions' (2006, xix). Aristotle similarly noted in his book on Nichomachean ethics that because good judgment is concerned with both the particulars and universals and because an appreciation of the particulars comes through experience and time is needed to produce it young people lack experience. Undoubtedly this makes phronesis harder to achieve for the inexperienced - the young - something which places an onus on youth work educators to ensure graduates have a beginning level of phronetic practice to help safeguard them against making too many major mistakes and to ensure that with experience they become phronetic practitioners.

One strength of the virtue ethics tradition is its conviction that the virtues can be learnt and that good character is the product of a good education. For Smith, the skill, knowledge and disposition required to make this connection can be learned and practiced. It is a difficult, yet indispensable element of professional practice and effective youth work. It can mean the difference between folding under the immediacy of the situation by identifying too strongly with events to the point where feelings override 
one's ability to see what is happening and being able to have some distance, but still connect understand (Smith 1994, p., 17, Smith and Smith 2008, Young 1999).

Phronesis is what some contemporary philosophers like Finnis and Williams call 'practical reasonableness'. It calls for a sensitivity to context, a capacity to know when and how we ought to act and in what measure. It rests on a sensibility to know on the part of the worker what circumstances require the exercise of particular virtues and most importantly when those virtues need to be moderated so as not to become failings and the cause of harm (ie,.., courage and recklessness). It relates to the idea of the 'golden mean' or balance when too little or an excess of a virtue becomes a vice. (Courage eg is situated between the vices of cowardice and foolhardiness).

Phronesis requires an ability to grasp and recognize the significance or value of the experiences for those involved in that particular situation. It entails making adjustments in line with a clear and informed grasp of the various competing interests at stake in a given context as well as understanding how those demands and interests change, and then being able to provide a measured response.

Examples of people who engage in phronetic practice I refer to Bent Flyvberg's case study of urban planning in Denmark and his work in social science research (2001, 2002, pp 353-366). For more youth work specific examples of how phronesis and virtue ethics can inform practice I refer to Smith's (1994) account of youth work and local education in England as well as Smith and Smiths later work (2008).

For Smith, good judgment in youth work requires an ethnographer's sensibility to both stand inside and outside a given situation in ways that allows them to link aspects of the local lived experience to the global and bring both together in ways that helps prevent poor judgment. Smith refers to poor judgment caused by the worker being either too close to, or too removed or remote from the daily lives of those they work with. The skill in appreciating the 'immediacy of the local' as well as the 'abstract or global' according to Smith allows the youth worker to better recognize what is happening and how best to respond. Standing outside can help a practitioner recognise for example that what they are observing in an immediate social context is a particular form of age based discrimination, which has become so ingrained, acceptable and normative to that social milieu that those who are part if it and too close can no longer see it in the way an outsider might. While standing from the 'experience distant' and observing from 'the abstract' may help us see discriminatory behaviour that had become 'normal' more easily, on its own it may not be enough because the emotional connection to the local as well as the practicalities of applying the abstract are less likely to be present without the inside perspective or 'experience near'. Moreover, the 'experience near' provides insight into the impact of that discrimination on the lived experience and not simply an abstracted or theoretical notion of prejudice that forms part of an expert discourse.

\section{Education}

A key advantage of virtue ethics for youth work is its emphasis on education and particularly the recognition of its transformative capacity. Identifying and pursuing the virtues and developing skills associated with good judgment and practice offers a hands-on pathway through which youth work can be practiced in ways that focus on enabling young people and workers to flourish. In this way virtue ethics is regarding of others, and not as some critics maintain primarily concerned with the agent's own acquisition of virtues and character development.

Virtue ethics indicates how youth work educators can develop curriculum, and learning experiences that challenge traditional and routinised approaches which tend to reproduce common-sense or prejudicial ideas about 'youth'. And as Tucker points out, educators have the job of shaping knowledge that defines youth work (2004: 87). By emphasizing character development virtue ethics holds promise for building and consolidating a clearly defined set of youth work skills and practices that can help achieve material changes which encourage the development of the young person's own practice of virtue.

The emphasis on education suits youth work if we recognise its informal educative role, and especially its capacity to encourage young people to develop good habits, become decent people, and think and act well. It orients youth work towards the task of developing the young person in the 
broad sense, while speaking about social goods, and their relevance to a flourishing life.

This optimistic feature of virtue ethics has value because it recognises our own capacities to shape the world, to play a formative role in securing social goods and our influencing the social contexts in which we live. In short it is a helpful ethical framework for youth work because it recognises human agency or our self-determining capacity. This can be used to counter popular functionalists and similar accounts of the individual as primarily governed by external forces such as 'social determinants', and thus an agent largely devoid of moral

\section{Conclusion}

In the context of ongoing debates about the kinds of ethical ideas that might inform youth work I made the case that virtue ethics provides a strong basis for both educating youth workers and informing good youth work practice; indeed that a natural affinity exists given the general intention towards character development that informs youth work. I suggested that the two dominant ethical frameworks, namely, utilitarianism and deontic ethics were not sufficiently specific about the nature of the goods and have a number of other limitations that make them inappropriate.

I argued that virtue ethics is directly relevant to modern youth work because it identifies and specifies the nature of the goods, and provides a relevant vocabulary and a framework of thinking about good practice. Six key considerations were adduced as to why virtue ethics provides a useful practical framework. They included its account of virtues expressed in our character, its focus on education to build character as a source of social transformation, its emphasize on our agential capacity to make choices, its interest in our capacity to think critically and act ethically, the connections it makes between the practice of virtues and social goods that define a good life individually or collectively, and its capacity to inform good professional judgment and good practice. What all this means for youth work was considered through discussions about good judgment and practice - or to use the virtue ethics vocabulary, 'phronesis'. What all that means in terms of the requisite skills, knowledge and dispositions is spelt out in relation to youth work practice.

What all this means for youth work and also what the key 'social goods' might look like were considered followed by a discussion on good judgment and good practice - or to use the virtue ethics vocabulary, 'phronesis'. What that means in terms of the requisite skills, knowledge and dispositions was spelt out in relation to the field of youth work practice.

\section{References}

Anscombe, G.E.M., 1958 Modern Moral Philosophy, Blackwell, Oxford.

Aristotle 1976, Ethics, (Trans J. Barnes), Penguin, Harmondsworth.

Ayer, A., 1947, The foundations of Empirical Knowledge, London, Macmillan.

Baier A., 1985, Postures of the Mind, Minneapolis: University of Minnesota Press.

Banks, S. 1999, Ethical Issues in Youth Work. Routledge, London

Banks, S. 2004 Ethics, Accountability and the Social Professions, Palgrave Macmillan.

Basingstoke and New York,

Davies, B., 2005, Youth Work; A Manifesto For Our Times, Youth and Policy, 88, pp.5-28.

Finnis, J., 1980, Natural Law and Natural Rights, Oxford University Press, Oxford.

Flyvbjerg, B., 2001, Making Social Sciences Matter, Cambridge University Press, Cambridge.

Foot, P., 1978, Virtues and Vices, CUP, Cambridge.

Gill, A, 1997, Orphans of the Empire: The Shocking Story of Child Migration to Australia, Sydney, Vintage.

Grogan, P., 2004, 'That old chestnut: the Professionalisation of youth work in Victoria', Youth Affairs Council of Victoria.

Hamilton,S., and Hamilton, M., 2007, The Youth development Handbook, Coming of Age in American Communities, Sage Thousand Oaks.

Human Rights and Equal Opportunity Commission, (HREOC) 1997, Bringing them home: Report of the National Inquiry into the separation of Aboriginal and Torres Strait Islander Children from their families, Sydney, Sterling Press.

Hursthouse R., 1999, On Virtue Ethics, Oxford, OUP.

Jeffs, T. and Smith, M. 2002, Individualisation and Youth Work', Youth and Policy, No. 76, pp. 39-65. 
Jeffs, T. and Smith, M., 2008, Valuing Youth Work, Youth and Policy, no.100, pp. $277-302$.

Kamm, F. M. 2007, Toward the Essence of Nonconsequentialist Constraints on Harming,' In Intricate Ethics: Rights, Responsibilities, and Permissible Harm. Oxford: OUP.

Koonz, C., 2004, The Nazi Conscience, Yale University Press, New Haven.

Macintyre, A., 1971, After Virtue, University of Notre Dame Press, Notre Dame.

Males, M., 1999, Framing Youth: 10 Myths about the Next Generation, Common Courage, Maine.

Nussbaum, M. 2000, Women and human development: The capabilities approach. Cambridge University Press, Cambridge.

Nussbaum. M., 2004, Mill between Aristotle and Bentham, Daedalus, v.133, pp.60 - 68.

Oakley, J. \& Cocking, D., 2001, Virtue Ethics and Professional Roles, CUP.

Palmer, D, 2003, Youth work, Aboriginal young people and ambivalence, Youth Studies Australia, v.22, n.4, pp.11-18.

Putnam, H., 2004, The collapse of the Fact-Value Dichotomy and Other essays, Harvard University Press, Cambridge.

Ross, W.D. 1930. The Right and the Good. Oxford: Clarendon Press.

Sercombe, H. 1998, Power, Ethics and youth work, Youth Studies Australia, v.17, n.1, pp.18-23.

Slote, M, 2001, Morals from Motives, Oxford, Oxford University Press.

Smith, M., 1988, Developing Youth Work, Informal education, mutual aid and popular practice, Milton Keynes/Open University Press.

Smith, H., Smith, M., 2008, The Art of Helping Others: Being Around, Being There, Being Wise, Peter Lang NY.

Spence,J., Devanney, C., Noonan,K., 2006, Youth work Voices, Durham and Weston Spirit, UK.

Tucker, S., 2004, Youth Working: Professional Identities Given, Received or Contested? In Roche, J., Tuckers, S., Thomson, R., Flynn, R, Youth in Society: contemporary theory, policy and practice, Sage \& OUP, London, pp. $81-101$.

van Hooft, S., 2006, Understanding Virtue Ethics, Acumen, Chesham.

Weber, M., 1978, Economy and Society: An Outline of Interpretative Sociology, Berkeley: UCLA Press.

Williams, B., 2006, Limits of Ethics and the Limits of Philosophy, Routledge.

Young, K.,1999, The Art of Youth work, Russell House publishing.

Youth Affairs Council of Victoria, 1996, The Great Debate, Youth Issues Forum, Winter,, 3, pp, 22-24.

Youth Affairs Council of Western Australia, (YACWA) 2003, Code of Ethics. YACWA. 